\title{
Diet and nutrition therapy in pre-liver transplant patients
}

\section{Neha Bakshi, Kalyani Singh}

Lady Irwin College, Department of Foods and Nutrition, University of Delhi, New Delhi 110001, India.

\begin{abstract}
Malnutrition is universally prevalent among pre-liver transplantation patients. Malnutrition among cirrhotic patients had been associated to increased morbidity and mortality rates. Also, severely malnourished patients before the transplant surgery have a higher rate of complications and a decreased overall survival rate after liver transplantation. In light of the high incidence of malnutrition and associated complications, it is essential to initiate treatment as early as it is assessed. This review addresses the aetiologies of malnutrition and appropriate treatment strategies to correct it in pre-liver transplant phase. Treatment should focus on maintaining nutrient intake and correcting various nutritional deficiencies. The dietician plays an integral role as part of the transplant team by providing appropriate nutrition therapy for solving various nutrition problems.
\end{abstract}

Key words: End stage liver disease; liver transplantation; pre-liver transplant

\section{Corresponding Author:}

Ms. Neha Bakshi, Lady Irwin College, Department of Foods and Nutrition, University of Delhi, Sikandra Road, Mandi House, New Delhi 110001, India. E-mail: nehabakshi.9@gmail.com

Received: 30-01-2016, Accepted: 04-07-2016

\section{INTRODUCTION}

Liver transplantation (LT) revolutionized the management of liver disease. LT is the only option for those with end stage liver disease (ESLD).$^{[1]}$ According to Institute of Health Metrics and Evaluation of Global Burden of Disease, deaths from cirrhosis in all age groups is ranked 12th globally and 19th in South Asia in 1990 and was ranked 12th globally and 11th in South Asia in the year 2010. Hence, an increasing death from cirrhosis is seen in South Asia over a period of time. ${ }^{[2]}$

\section{METABOLIC CHANGES IN ESLD}

Various metabolic changes that occur in ESLD patients are presented in Table $1^{|3-7|}$ which affect the nutrition state of pre-LT recipients. These factors are inadequate dietary intake, increased intestinal protein losses, malabsorption, low protein synthesis, hypermetabolism and disturbed substrate utilization. ${ }^{[8,9]}$

\begin{tabular}{|l|c|}
\hline \multicolumn{2}{|c|}{ Access this article online } \\
\hline \multirow{2}{*}{ Website: } & Quick Response Code \\
http://www.hrjournal.net/ & \\
\hline &
\end{tabular}

\section{CONSEQUENCES OF PREOPERATIVE MALNUTRITION ON LIVER TRANSPLANTATION OUTCOME}

Survival in cirrhosis decreases according to the severity of malnutrition. ${ }^{[10,11]}$ Preoperative hypermetabolism and body cell mass depletion was proven to be better predictors of the outcome of LT than the traditional Child-Pugh score. ${ }^{[12]}$ Undernutrition may induce an exaggerated cytokine response favouring postoperative systemic inflammatory response syndrome and multi-organ failure in these patients. ${ }^{[13]}$ Zinc deficiency is a precipitating factor for hepatic encephalopathy ${ }^{[14]}$ Deficiencies of water-soluble vitamins (B and $\mathrm{C}$ ) and fat soluble vitamins (A, E, D, and $\mathrm{K}$ ) may occur in patients with cirrhosis which increases the susceptibility of cell membranes to lipid peroxidation. ${ }^{[8]}$ Low retinol levels leads to an increased risk of developing hepatocellular carcinoma. ${ }^{[15]}$

Hence, careful nutritional assessment of candidates for LT is very important because the nutritional status of these patients may ultimately influence morbidity and mortality. Unfortunately, no gold standard exists to determine the extent of malnutrition in this population. ${ }^{[16]}$ An suitable nutritional

This is an open access article distributed under the terms of the Creative Commons Attribution-NonCommercial-ShareAlike 3.0 License, which allows others to remix, tweak, and build upon the worknon-commercially, as long as the author is credited and the new creations are licensed under the identical terms.

For reprints contact: service@oaepublish.com

How to cite this article: Bakshi N, Singh K. Diet and nutrition therapy in pre-liver transplant patients. Hepatoma Res 2016;2:207-15. 
Table 1: Metabolic changes in ESLD for liver transplant candidates $^{[5-7]}$

\begin{tabular}{lc}
\hline Metabolic changes & Abnormalities \\
\hline Glucose metabolism & Insulin resistance; \\
& depleted hepatic glycogen stores; \\
& fat is utilized as the main substrate for \\
energy, increased gluconeogenesis, lipid \\
oxidation and protein catabolism \\
Increased protein catabolism; \\
Protein metabolism & amino acid metabolism alterations; \\
& imbalance of BCAA and aromatic amino \\
& acids \\
Lipid metabolism & Polyunsaturated fatty acids deficiency; \\
& deficiency of essential fatty acid and \\
& long-chain polyunsaturated fatty acids \\
\hline
\end{tabular}

ESLD: end stage liver disease; BCAA: branched-chain amino acids

Table 2: Formula for REE ${ }^{[18,19]}$

\begin{tabular}{lc}
\hline Gender & Formula \\
\hline For males & REE $(\mathrm{kcal})=66+13.7 \times \mathrm{W}(\mathrm{kg})+5 \times \mathrm{H}(\mathrm{cm})$ \\
& $-6.8 \times \mathrm{A}($ years $)$ \\
For females & REE $(\mathrm{kcal})=655+9.6 \times \mathrm{W}(\mathrm{kg})+(1.7 \times \mathrm{H}(\mathrm{cm})$ \\
& $-4.7 \times \mathrm{A}$ (years) \\
\hline
\end{tabular}

REE: resting energy expenditure

assessment can include combination of nutrition tools like anthropometry, body composition analysis, subjective global assessment, and hand grip strength to formulate a composite score for assessment of malnutrition. ${ }^{[17]}$

\section{NUTRITION TREATMENT FOR PRE-LIVER TRANSPLANT PATIENTS}

The goals of nutritional therapy are to improve protein energy malnutrition and correct nutrient deficiencies. This can be accomplished by meeting nutrient requirements.

\section{Energy requirement}

When energy expenditure is related to lean body mass, patients with advanced liver disease have increased resting energy expenditure (REE). ${ }^{[18,19]}$ Despite the usually offsetting errors of excess total body water in estimation of REE from the Harris-Benedict equation [Table 2] ${ }^{[18,19]}$ it is still considered useful to measure the REE by way of indirect calorimetry in some patients with severe liver disease. Increased REE (hypermetabolic) was found over controls in patients with cirrhosis. But this is not a uniform finding since hypometabolism as well as normometabolism have been observed in patients with cirrhosis. ${ }^{[19-21]}$ When related to predicted energy expenditure among stable cirrhotics, a subgroup of $15-20 \%$ may be considered as hypermetabolic, $25-30 \%$ as hypometabolic and the large majority as normometabolic. ${ }^{[21]}$ Increased REE has also been observed during complications of liver disease, such as acute hepatic failure, ${ }^{[18]}$ high volume ascites, ${ }^{[22]}$ or presence of hepatocellular carcinoma. ${ }^{[23]}$ Measurements of total energy expenditure in patients with cirrhosis indicate that the $24 \mathrm{~h}$ energy requirement of cirrhosis patients amounts to about $130 \%$ of the basal metabolic rate (BMR)..[24] Diet-induced
Table 3: Nutrition in chronic liver disease-recommendations $1997^{[45]}$

\begin{tabular}{|c|c|c|}
\hline $\begin{array}{l}\text { Clinical } \\
\text { condition }\end{array}$ & $\begin{array}{c}\text { Non-protein } \\
\text { energy } \\
\text { (kcal/kg per day) }\end{array}$ & $\begin{array}{l}\text { Protein or amino acid } \\
\text { (g/kg per day) }\end{array}$ \\
\hline $\begin{array}{l}\text { Compensated } \\
\text { cirrhosis } \\
\text { Complications }\end{array}$ & $25-35$ & $1.0-1.2$ \\
\hline $\begin{array}{l}\text { Inadequate } \\
\text { intake } \\
\text { Malnutrition }\end{array}$ & $35-40$ & 1.5 \\
\hline $\begin{array}{l}\text { Encephalopathy } \\
\text { I-II }\end{array}$ & $25-35$ & $\begin{array}{c}\text { Transiently } 0.5 \text {, then } \\
\text { 1.0-1.5 if protein intolerant: } \\
\text { vegetable } \\
\text { protein or BCAA supplement }\end{array}$ \\
\hline $\begin{array}{l}\text { Encephalopathy } \\
\text { III-IV }\end{array}$ & $25-35$ & $\begin{array}{c}\text { 0.5-1.2 BCAA-enriched } \\
\text { solution }\end{array}$ \\
\hline
\end{tabular}

BCAA: branched-chain amino acids

thermogenesis ${ }^{[25,26]}$ and the energy cost of defined physical activity in stable cirrhosis patients ${ }^{27,28 \mid}$ and it also shows no deviation from values obtained in healthy patients. The spontaneous physical activity level is also low in cirrhotics. ${ }^{[5,28]}$

In cirrhotics without ascites, the actual body weight should be used for the calculation of the BMR using Harris and Benedict formulae. In patients with ascites the ideal weight according to body height should be used. In general, non-protein energy provision of $1.3 \times$ REE is sufficient. ${ }^{[29,30]}$ For most patients, the daily caloric need equals (1.2-1.4) $\times$ REE $(25-30 \mathrm{kcal} / \mathrm{kg}$ body weight).

Administration of adequate calories is critical for the efficient use of protein sources, particularly when patients are protein restricted. Excess calories particularly from carbohydrate, should be avoided because it promotes hepatic lipogenesis, liver dysfunction and increased carbon dioxide production leading to increased work of breathing. ${ }^{[31]}$

For patients with steatorrhea, it is important to limit long-chain fatty acids and increase short-chain and medium-chain fatty acids in the formula. Pancreatic enzymes should be supplemented, especially in patients with alcohol-related cirrhosis. ${ }^{[32]}$ The serum lipid variables appeared to be more useful indicators of functional liver improvement than the classic liver function tests. ${ }^{[33]}$

\section{Protein requirements}

In clinical intervention trials proteins were given in amounts of 0.6-1.2 g/kg per day for patients with cirrhosis and severe encephalopathy ${ }^{\mid 34]}$ and $0.5-1.6 \mathrm{~g} / \mathrm{kg}$ per day in patients with alcoholic hepatitis with or without low grade encephalopathy. ${ }^{[35]}$ Patients with stable cirrhosis appear to have increased protein requirements of $1.2 \mathrm{~g} / \mathrm{kg}$ per day to maintain nitrogen homeostasis as opposed to $0.8 \mathrm{~g} / \mathrm{kg}$ per day in normal individuals. ${ }^{[36]}$ The reasons for this phenomenon are not yet clear, but the increased protein requirement seems to be due to increased whole body protein degradation which may be due to low plasma levels of insulin-like 
Table 4: Nutrition recommendations for a liver transplant candidate $^{[58-63]}$

\begin{tabular}{|c|c|}
\hline Nutrient & General recommendations \\
\hline Calories & $\begin{array}{c}\text { Energy needs vary with each individual; } \\
30-35 \mathrm{kcal} / \mathrm{kg} \text { dry weight for maintenance; } \\
35-40 \mathrm{kcal} / \mathrm{kg} \text { dry weight for malnourished } \\
\text { patients; } \\
25-35 \mathrm{kcal} / \mathrm{kg} \text { dry weight for hepatic } \\
\text { encephalopathy; } \\
\text { (calculated on dry weight) }\end{array}$ \\
\hline Proteins & $\begin{array}{c}\text { 0.8-1.0 g/kg dry weight in compensated liver } \\
\text { disease; } \\
\text { 1.5-2.0 g/kg dry weight in decompensated liver } \\
\text { disease; } \\
\text { 0.6-1.0 g/kg dry weight for hepatic } \\
\text { encephalopathy, BCAA-enriched formulas }\end{array}$ \\
\hline Fats & $\begin{array}{l}25-40 \% \text { of calories, moderate amounts of medium } \\
\text { chain triglycerides oil when steatorrhea present }\end{array}$ \\
\hline Carbohydrates & $\begin{array}{c}\text { Restrict simple carbohydrate if glucose } \\
\text { intolerance is present }\end{array}$ \\
\hline Sodium & 2-4 g/day depending upon level of fluid retention \\
\hline Fluid & $\begin{array}{c}1,000-1,500 \mathrm{~mL} / \text { day if fluid retention or } \\
\text { hyponatremia is present }\end{array}$ \\
\hline Vitamins & $\begin{array}{c}\text { Fat malabsorption leads to malabsorption of } \\
\text { fat-soluble vitamins; } \\
\text { vitamin A: liver unable to synthesize } \\
\text { retinol-binding protein; } \\
\text { vitamin D: decreased biliary excretion of } \\
\text { 1,23-dihydroxycholecalciferol; } \\
\text { vitamin E: cholestatic liver disease affect vitamin } \\
\text { E because it is carried by lipoproteins; } \\
\text { B vitamins: excess losses due to alcohol abuse }\end{array}$ \\
\hline Minerals & $\begin{array}{l}\text { Mineral bioavailability, tissue distribution, and } \\
\text { toxicity can be affected by decreased liver } \\
\text { production of their protein carriers; } \\
\text { manganese and copper excretion in bile affected } \\
\text { by an interruption in enterohepatic circulation; } \\
\text { Serum potassium, magnesium, and phosphorus } \\
\text { levels may decrease as a result of diuretic } \\
\text { administration, refeeding syndrome, } \\
\text { malabsorption, or alcoholism; } \\
800-1,200 \text { mg calcium/day }\end{array}$ \\
\hline
\end{tabular}

growth factor (IGF)-1. ${ }^{[19]}$

According to Morgan et al. ${ }^{[37]}$ (2006) whole protein formula providing 35-40 kcal/kg per day energy and 1.2-1.5 g/kg per day protein is recommended for enteral feeding. Standard preparation contains approximately $100 \mathrm{kcal}, 4 \mathrm{~g}$ protein, and $3.5 \mathrm{mmol}$ of sodium and potassium per $100 \mathrm{~mL}$. Concentrated high energy $(1.5 \mathrm{kcal} / \mathrm{mL})$ and protein formulas may be preferable in patients with hyponatremia and ascites to regulate fluid balance. This may also improve treatment adherence because less volume needs to be consumed.

A study by Nielsen et al. $^{[38]}$ (1995) showed protein balance in a subgroup of patients did not change protein balance values.
Protein intake increased from $1.0 \mathrm{~g} / \mathrm{kg}$ per day to $1.8 \mathrm{~g} / \mathrm{kg}$ per day. With increasing protein intake, $84 \%$ of the increase in intake was retained. The rate of protein retention was not saturated at the intakes obtained in this study.

Protein requirement and protein utilization were investigated further by measuring protein synthesis and degradation. In 2 separate studies, patients with cirrhosis of the liver were refed on a balanced diet for an average of 2-4 weeks. Protein and energy intakes were doubled in both studies. Refeeding caused a statistically significant increase of about 30\% in protein synthesis in both studies while protein degradation was only slightly affected. The increase in protein synthesis was associated with significant increases in plasma concentrations of total amino acids while insulin, growth hormone, IGF-1 and IGF-3 were not changed significantly. The results indicate that the efficient protein utilization is due to increased protein synthesis, rather than decreased protein degradation. ${ }^{[5]}$

\section{Value of branched-chain amino acids}

Branched-chain amino acids (BCAAs) (leucine, isoleucine, valine) are essential amino acids. In cirrhosis, there is a likely reduced total body pool of BCAAs due to reduced lean muscle mass and defective use secondary to hyperinsulinemia. ${ }^{[39}$

BCAAs compete with the serotonin precursor tryptophan for the same amino acid transporter in the blood-brain barrier and the imbalance between the 2 in cirrhosis influences brain ammonia levels directly or indirectly. ${ }^{[0]}$ So supplementation with BCAAs may reduce brain uptake of tryptophan and improve encephalopathy. ${ }^{[41,42]}$ Furthermore, BCAA supplementation by both enteral and parenteral routes of feeding has shown improved in cerebral perfusion by which encephalopathy may get improved but still basic mechanism is unclear. A large multicenter study showed that oral BCAAs given for 1 year improved the Child score, reduced hospital admissions, and prolonged/improved event-free survival. ${ }^{[43]}$ However, there have been no controlled studies and no mention of the timing of BCAA supplementation in cirrhotic patients. ${ }^{[44]}$ At 3 months, a significant increase in serum albumin level was observed in patients who were administered with nocturnal BCAAs but not daytime BCAAs. It is hypothized that BCAAs when consumed in daytime are utilized as calories, whereas nocturnal BCAAs are utilized for protein synthesis. ${ }^{[39]}$ European Society for Parenteral and Enteral Nutrition (ESPEN) guidelines [Table 3] ${ }^{[45]}$ recommends use of enteral feed enriched with BCAAs for patients who develop encephalopathy. The use of solutions rich in BCAA and low in aromatic acids and tryptophan in encephalopathy has been proposed. ${ }^{[46]}$ However, a Cochrane analysis based on 11 trials found no convincing evidence regarding benefit from BCAA. The use of BCAAs remains controversial, and they are not widely available in many centres due to their expense and unpalatability. ${ }^{[47]}$

According to ESPEN Guidelines, for a positive effect on liver function and clinical outcome, non-protein energy 
Table 5: Major studies recommending use of nutrition supplementation

\begin{tabular}{|c|c|c|}
\hline Study & Recommendations & Outcomes \\
\hline Bories and Campillo ${ }^{[32]}$ (1994) & $40 \mathrm{kcal} / \mathrm{kg}$ per day & $\begin{array}{l}\text { Protein and energy intakes were significantly higher; } \\
\text { improved nutritional satus; } \\
\text { improved biochemical parameters }\end{array}$ \\
\hline Hirsch et al. ${ }^{[81]}$ (1993) & $\begin{array}{c}1,000 \mathrm{kcal} \text { and } 35 \mathrm{~g} \text { of nitrogen/day for } \\
1 \text { year }\end{array}$ & $\begin{array}{l}\text { Need for hospitalization was significantly lower in the } \\
\text { supplemented; } \\
\text { reduction of infectious complications; } \\
\text { a lower mortality in the therapeutic group }\end{array}$ \\
\hline Mendenhall et al. ${ }^{[82]}$ (1993) & $>2,500 \mathrm{kcal} /$ day & $\begin{array}{l}51 \% \text { mortality in severe malnourished patients with } \\
\text { inadequate caloric intake; } \\
\begin{array}{l}19 \% \text { mortality in patients who received adequate oral } \\
\text { nutrition }\end{array}\end{array}$ \\
\hline Le Cornu et al. ${ }^{[83]}(2000)$ & $\begin{array}{l}\text { Nutritional supplementation to } \\
\text { pre-transplant candidates }\end{array}$ & $\begin{array}{l}\text { Did not increase overall dietary energy or protein intake } \\
\text { and did not significantly improve post- transplant } \\
\text { outcome; regular dietary counselling is as effective in } \\
\text { increasing energy intake }\end{array}$ \\
\hline Kawaguchi et al. ${ }^{[84]}(2008)$ & 200-kcal nutritional supplement & $\begin{array}{c}\text { Stress scores for physical and mental symptoms were } \\
\text { significantly lower compared to those in the fasting } \\
\text { group }\end{array}$ \\
\hline
\end{tabular}

was given in amounts of 35-40 kcal/kg per day plus protein up to $1.6 \mathrm{~g} / \mathrm{kg}$ per day. In patients with encephalopathy, transient protein restriction can be instituted, but after a few days adequate nutrition should be reinstituted. Patients in coma (encephalopathy grade III-IV) can safely be given total parenteral nutrition (TPN) regimens providing $25-30 \mathrm{kcal} / \mathrm{kg}$ per day from non protein energy plus $1.0 \mathrm{~g} / \mathrm{kg}$ per day using BCAA-enriched solutions. Fasting periods should not exceed $6 \mathrm{~h}$ due to the limited glycogen stores in malnourished cirrhotic patients. Generally, the oral or enteral routes are preferred. Parenteral nutrition should only be used when enteral feeding is not possible or impractable [Table 3]. ${ }^{\mid 45]}$

\section{Micronutrients requirements}

Micronutrient deficiency has been observed in $10-50 \%$ of patients with cirrhosis. Multivitamin supplements may be considered in these patients. ${ }^{|48|}$

\section{Vitamins}

Various vitamins deficiency occurs in LT recipients like folate deficiency is due to a combination of decreased intake, decreased absorption, as well as losses from renal excretion and poor hepatic storage. Supplementation of folate and B12 is crucial in alcoholic hepatitis to protect uninjured hepatocytes and stimulate the repair/replacement of damaged cells [Table 4]. The common recommendation for folate supplementation is $1 \mathrm{mg} /$ day orally. ${ }^{[48]}$ Vitamin B1 deficiency is linked to primary tissue damage such as alcoholic polyneuropathy and also Wernicke's encephalopathy. Usual supplementation is $100 \mathrm{mg} /$ day orally or subcutaneously initially for 2 weeks or until repleted, the amount in a standard multivitamin should be sufficient. ${ }^{[48]}$ Deficiency of vitamin B6 (pyridoxine) is due to decreased intake or altered metabolism and storage. Standard supplementation is 50$100 \mathrm{mg} /$ day orally, or more in severely depleted individuals. ${ }^{[49]}$ Liver stores are often depleted even in the setting of normal serum levels. ${ }^{[50]}$ Hypovitaminosis A has been linked to night blindness, impairment in immune function, and also to an increased risk of hepatic fibrosis [Table 4]. If malabsorption is suspected as a prime contributor to depletion, doses of 25,000-50,000 IU 3 times per week may be needed for repletion. Vitamin A supplementation improves the sense of taste and thereby may also improve dietary intake of the patients. ${ }^{[14]}$ Inadequate intake of calcium and vitamin D and losses from malabsorption and renal excretion are related to lower serum levels of albumin and magnesium. ${ }^{[49]}$ If the individual is unable to increase dietary intake to a consistent, adequate level of 1,000-1,500 mg/day, supplementation should be initiated, especially in those with suspected low bone mineral density. Osteoporosis has been confirmed in $17-23 \%$ of patients with liver disease. The role of vitamin D and calcium on bone mass in the setting of liver disease is unclear.$^{[51]}$ Serum levels should be monitored in 3 months to assess tolerance and success of repletion. Low serum levels of vitamin $D$ are thought to be the result of poor dietary intake, malabsorption from cholestasis, pancreatic insufficiency, and decreased sunlight exposure.|52] Supplementation usually begins at $400 \mathrm{IU}$ per day, with some patients requiring up to $800 \mathrm{IU}$ per day of vitamin D or 12,000-50,000 IU per day of ergocalciferol, with serum levels reassessed in 2-3 months. ${ }^{|53|}$ Serum vitamin E levels are typically decreased in alcoholic patients, pancreatitis or fat malabsorption [Table 4]. A dose of $400 \mathrm{IU}$ per day either as standard vitamin $\mathrm{E}$ or as $\alpha$-tocopherol, if malabsorption is suspected, should provide for adequate supplementation in most individuals. ${ }^{[49]}$

\section{Minerals}

During the pre-LT phase patients suffer from various mineral deficiencies because of metabolic changes due to liver impairment. Zinc deficiency is very common in cirrhotics. ${ }^{|54|}$ Zinc supplementation may also be used for those patients with hepatic encephalopathy, with refractory response to vitamin A supplementation for night blindness, and 
Table 6: Guidelines for pre-transplant nutrition support ${ }^{[31,37,63,89,90]}$

\begin{tabular}{|c|c|}
\hline ESPEN Guidelines & Recommendations for nutrition \\
\hline \multirow[t]{5}{*}{ For organ transplantation 2006} & Under nutrition majorly influence outcome after LT; \\
\hline & use additional oral nutrition supplementation or even tube feeding; \\
\hline & EN improves nutritional status and liver function, reduces the rate of \\
\hline & complications, cost and prolongs survival; \\
\hline & assess nutritional status regularly \\
\hline \multirow[t]{11}{*}{ For enteral nutrition for liver disease 2006} & Use high-energy formulae in patients with ascites; \\
\hline & increased protein requirements; \\
\hline & use BCAA-enriched formulae (hepatic encephalopathy); \\
\hline & EN and probiotic formula reduces the incidence of infections; \\
\hline & hepatic encephalopathy must be treated with lactulose or rifaximin; \\
\hline & normal protein diets can be given safely to patients with hepatic \\
\hline & encephalopathy; \\
\hline & recommended protein supplementation is based on "dry" body \\
\hline & weight; \\
\hline & recommended to insert fine bore nasogastric tubes in patients with \\
\hline & esophageal varices \\
\hline \multirow[t]{12}{*}{ For parenteral nutrition in hepatology 2006} & PN is indicated in unprotected airways, encephalopathy and \\
\hline & moderately or severely malnourished cirrhotics; \\
\hline & cirrhotics who have to abstain from food temporarily for $>12 \mathrm{~h}$ \\
\hline & should be given i.v. glucose at 2-3 g/kg per day. When this fasting \\
\hline & period lasts longer than $72 \mathrm{~h}$ TPN is required; \\
\hline & the i.v. provision of all macro- and micronutrients must be ensured \\
\hline & from the beginning of PN; \\
\hline & carbohydrate should be given as glucose to cover $50-60 \%$ of \\
\hline & non-protein energy requirements; \\
\hline & in case of hyperglycaemia glucose infusion should be reduced to 2-3 \\
\hline & lipid should be provided using emulsions, should cover $40-50 \%$ of \\
\hline & non-protein energy requirements \\
\hline
\end{tabular}

ESPEN: European Society for Parenteral and Enteral Nutrition; BCAA: branched-chain amino acids; LT: liver transplantation; EN: enteral nutrition; TPN: total parenteral nutrition

for potential improvement in immune function and taste perception. ${ }^{[49]}$ Supplementation in the form of $220 \mathrm{mg}$ zinc sulphate is given in 1-3 divided doses per day. Zinc and selenium deficiency has been observed in both alcoholic and non-alcoholic liver disease and may be associated with neurological symptoms. ${ }^{[55]}$ Depleted serum iron levels, blood losses can cause deficiency in LT patients. ${ }^{[49]}$ Hepatic iron overload is common and often secondary to increased intestinal iron absorption and transfusions, and may imitate hemochromatosis as well as increase the risk of developing progression of liver disease. ${ }^{[56]}$ Patients undergoing LT are prone to hypomagnesemia, with potential deleterious effects. A study evaluated the efficacy and safety of routine intraoperative magnesium supplementation to prevent hypomagnesemia. The results ${ }^{[57]}$ showed lower prevalence of postoperative hypomagnesemia in patients administered magnesium supplementation of $3 \mathrm{~g}$ [Table 4$]^{[58-63]}$ but may not affect the occurrence of arrhythmias.

\section{CHALLENGE IN PRE-TRANSPLANT NUTRITION SUPPORT}

Ascites, defined as the accumulation of fluid within the peritoneal cavity as a direct consequence of portal hypertension, is a common complication of ESLD and associated with a poor prognosis. ${ }^{[64]}$ The squeal of impaired renal perfusion and fluid volume expansion can precipitate hyponatremia as well. ${ }^{[65]}$ Spontaneous bacterial peritonitis may develop which is associated with increased mortality. ${ }^{[66]}$ Nutrition issues may occur in cirrhotics with ascites due to decreased intake from early satiety, increase in REE before paracentesis. Also, imposing dietary restrictions of sodium and fluid reduces the palatability of food. ${ }^{[22]}$

The American Association for the Study of Liver Disease practice guidelines (2004), recommend sodium restricted diet and diuretic therapy as the mainstay of treatment for ascites, with their effectiveness demonstrated in about $90 \%$ of patients. A dietary sodium restriction of $2 \mathrm{~g}$ /day appropriately balances the need for adequate nutrition and fluid status. The reduction in ascitic fluid through careful diuresis can relieve early satiety. A 24-h urinary sodium excretion with a goal of $\geq 78 \mathrm{mEq}$ urinary sodium per day can be measured to follow compliance to a sodium-restricted diet. A fluid restriction is appropriate in cirrhotic patients with dilutional hyponatremia or serum sodium levels $<125 \mathrm{mg} / \mathrm{dL}$ [Table 4]. Small, frequent feedings and an adequate intake of protein, in addition to the sodium restriction, are important dietary 
measures for the patient. Contraindication of these measures lead to large-volume paracentesis (intravenous albumin) or transjugular intrahepatic portosystemic shunt placement may be necessary. ${ }^{[6,67]}$

\section{OTHER NUTRITIONAL FACTORS}

\section{Probiotics}

Current evidences have shown the advantages of probiotic use in preventing post $\mathrm{LT}$ infection, as well as improving the hyperdynamic circulatory state of cirrhosis, hepatic encephalopathy, and Child-Pugh class. ${ }^{[68,69]}$ Its evaluated that neutrophil phagocytic capacity improved in cirrhotic and hepatic encephalopathy patients after probiotics supplementation which prevents infections by altering gut microbiota, preventing bacterial translocation and decreasing endotoxin levels which leads to the restoration of the immune system. ${ }^{[70-72]}$ The effect of probiotic mix $(8$ strains of Lactobacillus, Bifidobacterium and Streptococcus) for 2 months was assessed on portal hypertension, which showed no reduction on hepatic venous pressure gradient or bacterial translocation in patients with compensated or early decompensated cirrhosis. ${ }^{[73]}$ But, Lata et al. ${ }^{[74 \mid}$ (2007) observed a trend towards decreased endotoxemia and an improvement in Child-Pugh scores (results not statistically significant) with use of the Escherichia coli Nissle [(2.5-25) $\times 10^{9}$ bacteria in 1 capsula, for 42 days) in 39 cirrhotic patients.

\section{Immunonutrition}

The impact of nutritional interventions with immune modulating enteral diets in patients' pre- and post-LT showed possibility of improved preoperative nutritional status of ESLD patients, thus reducing infectious complications after transplantation. ${ }^{\text {[75] }}$ Qiu et al. ${ }^{[76}$ (2009) investigated the effect of TPN supplemented with alanyl-glutamine dipeptide in cirrhotic patients undergoing LT. Within 9 days, the group supplemented had a significant increase in the prognostic nutrition index and prealbumin levels compared with day 2 levels. It was observed better improvement in aspartate amino transferase and reduced hepatic cell injury compared with the traditional TPN group and a significant decrease in postoperative hospital stay.

\section{Nocturnal meals}

A study by Plank et al. ${ }^{[77]}$ (2008) showed the effects of nighttime and day time nutritional supplementation over a 12-month period on body protein stores in cirrhotic patients. Significant accretion of total body protein equivalent to about $2 \mathrm{~kg}$ of lean tissue was seen in patients having nighttime supplementation. In the daytime group, no significant accretion was seen. Confirming this, a classical study showed nocturnal supplementation in cirrhotic patients would improve and prevent catabolic states and under nutrition. ${ }^{\mid 78]}$

\section{ROUTES OF FEEDING}

\section{Nutrition supplementation}

Oral intake, including supplements, is the first line therapy to prevent and treat malnutrition in liver diseases. The data suggested that by providing medical nutrition therapy, nutrition status may be improved and complications of cirrhosis may be decreased (less hospital admissions, decreased hepatic encephalopathic symptoms, infections, gastrointestinal bleeding, ascites), although the true impact on survival is still unclear. ${ }^{[7,80]}$ Various studies recommending use of nutrition supplementation for LT patients are depicted in Table 5. $\cdot^{[32,81-84]}$

\section{Enteral and parenteral nutrition}

Studies show an increased dietary intake by oral nutrition, improves in liver function and lower hospital mortality than enetral and parenteral. ${ }^{[31,85]}$ Most of the well-nourished patients admitted with variceal bleeding and other complications failed to show benefit in nutritional status or disease-related morbidity and mortality. In hospitalized patients with poor dietary intake, enteral nutrition (EN) should be initiated in about $24-48 \mathrm{~h}$ of admission. ${ }^{[86]}$ Hasse et al. ${ }^{[87]}$ demonstrated early enteral feeding benefits like improved nitrogen balance and fewer viral infections after LT.

PN should be used as a second line approach in those who cannot be fed adequately by the oral or enteral route, patients with unprotected airways and advanced hepatic encephalopathy, after visceral surgery in cirrhotics, a lower complication rate was observed when postoperative PN was given instead of just fluid and electrolytes; usually standard amino acid formula is recommended. ${ }^{[16,88]}$ In a direct comparison between PN and early EN, both strategies proved to be equally effective with regard to the maintenance of nutritional state. ${ }^{[89]}$

\section{DISCUSSION}

Different mechanisms are known for the nutritional derangement in ESLD patients. These include malabsorption, poor dietary intake, low protein synthesis, higher intestinal protein losses, disturbances in substrate utilization, and hypermetabolism..$^{[8]}$ Poor dietary intake is one of the major contributors to ESLD malnutrition. Also, various metabolic disturbances like increased REE, insulin resistance, and low respiratory quotient which indicates decreased glucose and increased lipid oxidation which can contribute to nutritional depletion in liver disease ${ }^{.9}$ Early nutrition therapy intervention can improve response to treatment; alleviate symptoms, and quantity of life of ESLD patients. ${ }^{[9]}$ In this review, medical nutrition therapy goals for pre-LT patients are discussed. Various guidelines have been established for pre-LT nutrition care. ESPEN guidelines for chronic liver disease showed increased calorie and protein requirement in malnourished liver disease patients $(30-35 \mathrm{kcal} / \mathrm{kg}$ per day and $1.5 \mathrm{~g} / \mathrm{kg}$ per day). ${ }^{[45]}$ Also malabsorption of other nutrients increases requirements of other vitamins and minerals like $\mathrm{Ca}, \mathrm{Mg}$, vitamin A, B, D, E and complications like ascites recommends use of low sodium diet which can lead to hyponatermia. ${ }^{[64]}$ ESPEN guidelines for organ transplantation recommends enteral nutrition or oral nutritional supplementation which 
can improve nutritional status and survival in severely

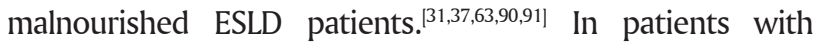
cirrhosis, enteral feeding improves nutritional status and liver function and reduces the rate of complications and prolongs survival. ${ }^{[91]}$ Another guideline that is ESPEN Guidelines for enteral nutrition for liver disease recommends use of more concentrated high-energy formulae in patients with ascites, BCAA-enriched formulae in hepatic encephalopathy patients. ${ }^{[87}$ Administration of enteral nutrition has been shown to reduce the incidence of viral and bacterial infections. ${ }^{[69,87]}$ Protein restriction is rarely required for encephalopathy patients, if necessary, usually for not more than $48 \mathrm{~h}$. The recommended protein supplementation should be based on "dry" body weight and may need alteration in edematous patients [Table 6]. ${ }^{[87]}$

ESPEN guidelines for parenteral nutrition in hepatology recommend indication and timing of PN in cirrhosis. Immediate commencement of PN is recommended in moderately or severely malnourished cirrhotics who cannot be nourished sufficiently by either oral or enteral route or patients who have to abstain from food temporarily (including nocturnal fasting), when this fasting period lasts longer than $72 \mathrm{~h}$ total $\mathrm{PN}$ is required. Carbohydrate should be given as glucose to cover $50-60 \%$ of non-protein energy requirements. PN related hyperglycaemia should be avoided by all means. In case of hyperglycaemia glucose infusion should be reduced to $2-3 \mathrm{~g} / \mathrm{kg}$ per day and i.v. insulin infusion should be used. Lipids should be provided using emulsions with a content of n-6 unsaturated fatty acids lower than in traditional pure soybean oil emulsions and should cover $40-50 \%$ of non-protein energy requirements. PN should be considered in patients with unprotected airways and encephalopathy when cough and swallow reflexes is compromised [Table 6]. ${ }^{[92]}$

These recommendations clearly portray the need for nutrition intervention among ESLD patients at the earliest to treat the nutrition medicated complications before LT for improved outcomes after the surgery and overall wellbeing of the ESLD patient.

\section{CONCLUSION}

Malnutrition is a well-known complication of ESLD and is associated with detrimental consequences if left untreated. It is, therefore, of critical importance to assess the nutritional status of all patients with ESLD and to optimize nutritional support in these patients. Treatment should focus on maintaining adequate protein and caloric intake and correcting nutrient deficiencies. The dietician plays an integral role as part of the transplant team by providing appropriate nutrition therapy for solving various nutrition problems. Strategies include the consumption of frequent small meals and a late evening snack to reduce protein breakdown. When oral intake is insufficient, early implementation of enteral feeding should be considered. The use of BCAAs remains controversial, but the most recent data promote their therapeutic potential.
Malnutrition is a potentially reversible condition that, when identified and treated appropriately, can lead to improved outcomes hence, more nutrition interventions should be planned with motive of attaining positive nutrition balance in patients undergoing LT.

\section{Financial support and sponsorship}

Nil.

\section{Conflicts of interest}

There are no conflicts of interest.

\section{REFERENCES}

1. Kasper DL, Braunwald E, Hauser S, Longo D, Jameson JL, Fauci AS. Harrison's Principles of Internal Medicine. 16th Ed. New York: The McGraw-Hill Companies; 2005. p. 1301-2608.

2. Institute for Health Metrics and Evaluation (IHME). GBD Heatmap. Seattle, WA: IHME, University of Washington, 2013. Available from: http://vizhub.healthdata.org/irank/heat.php

3. Cabre E, Gonzalez-Huix F, Abad-Lacruz A, Esteve M, Acero D, Fernandez-Bañares F, Xiol X, Gassull MA. Effect of total enteral nutrition on the short-term outcome of severely malnourished cirrhotics. Gastroenterology 1990;98:715-20.

4. McCullough AJ, Tavill AS. Disordered energy and protein metabolism in liver disease. Semin Liver Dis 1991;11:265-77.

5. Kondrup J, Muller MJ. Energy and protein requirements of patients with chronic liver disease. J Hepatol 1997;27:239-47.

6. Bathgate AJ, Hynd P, Sommerville D, Hayes PC. The prediction of acute cellular rejection in orthotopic liver transplantation. Liver Transpl Surg 1999;5:475-9.

7. Cabré E, Gassull MA. Nutritional and metabolic issues in cirrhosis and liver transplantation. Curr Opin Clin Nutr Metab Care 2000;3:345-54.

8. Cabré E, Gassull MA. Nutritional aspects of chronic liver disease. Clin Nutr 1993;12:S52-63.

9. Greco AV, Mingrone G, Benedetti G, Capristo E, Tataranni PA, Gasbarrin G. Daily energy and substrate metabolism in patients with cirrhosis. Hepatology 1998;27:346-50.

10. Mendenhall CL, Tosch T, Weesner R, Garcia-Pont P, Goldberg SJ, Kiernan T, Seeff LB, Sorell M, Tamburro C, Zetterman R. VA cooperative study on alcoholic hepatitis II: prognostic significance or protein-calorie malnutrition. Am J Clin Nutr 1986;43:213-8.

11. Abad A, Cabré E, Gonzalez Huix F. Influence of the nutritional status in the prognosis and clinical outcome of hospitalized patients with liver cirrhosis. Preliminary report. J Clin Nutr Gastroenterol 1987;2:63-8.

12. Selberg O, BoÈttcher J, Tusch G, Pichlmayr R, Henkel E, Muller MJ. Identification of high- and low-risk patients before liver transplantation. A prospective cohort study of nutritional and metabolic parameters in 150 patients. Hepatology 1997;25:652-7.

13. Miki C, Iriyama K, Mayer AD, Buckels JA, Harrison JD, Suzuki $\mathrm{H}$, McMaster P. Energy storage and cytokine response in patients undergoing liver transplantation. Cytokine 1999;11:244-8.

14. Riggio O,Ariosto F, Merli M, Caschera M, Zullo A, Balducci G, Ziparo V, Pedretti G, Fiaccadori F, Bottari E. Short-term oral zinc supplementation does not improve chronic hepatic encephalopathy. Results of a doubleblind crossover trial. Dig Dis Sci 1991;36:1204-8.

15. Newsome PN, Beldon I, Moussa Y, Delahooke E, Poulopoulos G, Hayes PC, Plevris JN. Low serum retinol levels are associated with hepatocellular carcinoma in patients with chronic liver disease. Aliment Pharmacol Ther 2000;14:1295-301.

16. Lochs H, Plauth M. Liver cirrhosis: rationale and modalities for nutritional support-the European Society of Parenteral and Enteral Nutrition consensus and beyond. Curr Opin Clin Nutr Metab Care 1999;2:345-9.

17. Bakshi N, Singh K. Nutrition assessment in patients undergoing liver transplant. Indian J Crit Care Med 2014;18:672-81.

18. Kleinberger G. Energy supply during parenteral nutrition in liver 
insufficiency. In: Holm E, Kasper H, editors. Metabolism and nutrition in liver disease. 1st ed. 41st Falk Symposium; 1985. p. 303-12.

19. Shanbhogue RL, Bistrian BR, Jenkins RL, Jones C, Benotti P, Blackburn GL. Resting energy expenditure in patients with end stage liver disease and in normal population. J Parenter Enteral Nutr 1987;11:305-8.

20. Schneeweiss B, Graninger W, Ferenci P, Eichinger S, Grimm G, Schneider B, Laggner AN, Lenz K, Kleinberger G. Energy metabolism in patients with acute and chronic liver disease. Hepatology 1990;11:38793.

21. Kleinberger G, Ferenci P, Riederer P, Thaler H. Advances in Hepatic Encephalopathy and Urea Cycle Diseases. Proceedings of 5th International Symposium on Ammonia, Semmering, Austria, May 1984. Basel: Karger Publication; 1984. p. 674-81.

22. DolzC, Raurich JM, IbanezJ, Obrador A, Mars P, GaytJ.Ascites increases the resting energy expenditure in liver cirrhosis. Gastroenterology 1991;100:738-44.

23. Merli M, Riggio O, Servi R, Zullo A, De Santis A, Attili AF, Capocaccia L. Increased energy expenditure in cirrhotic patients with hepatocellular carcinoma. Nutrition 1992;8:321-5.

24. Nielsen K, Martinsen L, Dossing H, Stilling B, Kondrup J. Energy expenditure measured by the doubly labeled water method during hyperalimentation of patients with liver cirrhosis. J Hepatol 1991;13:S151.

25. Campillo B, Bories PN, Sommer F, Wirquin E, Fouet P. The thermogenic and metabolic effects of food in liver cirrhosis: consequences on the storage of nutrients and the hormonal counter regulatory response. Metabolism 1992;41:476-82.

26. Muller MJ, Willmann O, Rieger A, Fenk A, Selberg O, Lautz HU, Bürger M, Balks HJ, von zur Mühlen A, Schmidt FW. Mechanism of insulin resistance associated with liver cirrhosis. Gastroenterology 1992;102:2033-41.

27. Campillo B, Fouet P, Bonnet JC, Atlan G. Submaximal oxygen consumption in liver cirrhosis. Evidence of severe functional aerobic impairment. J Hepatol 1990;10:163-7.

28. Muller MJ, Dettmer A, Tettenborn M, Radoch E, Fichter J, Wagner TO, Balks HJ, von zur Mühlen A, Selberg O. Metabolic, endocrine, haemodynamic and pulmonary responses to different types of exercise in individuals with normal or reduced liver function. Eur J Appl Physiol Occup Physiol 1996;74:246-57.

29. Plevak DJ, DiCecco SR, Wiesner RH, Porayko MK, Wahlstrom HE, Janzow DJ, Hammel KD, O'Keefe SJ. Nutritional support for liver transplantation: identifying caloric and protein requirements. Mayo Clin Proc 1994;69:225-30.

30. Weimann A, Kuse ER, Bechstein WO, Neuberger JM, Plauth M, Pichlmayr R. Perioperative parenteral and enteral nutrition for patients undergoing orthotopic liver transplantation. Results of a questionnaire from 16 European transplant units. Transpl Int 1998;11:S289-91.

31. Elwyn DH, Kinney JM, Askanazi J. Energy expenditure in surgical patients. Surg Clin North Am 1981;61:545-56.

32. De Ledinghen V, Beau P, Mannant PR, Ledinghen VD, Beau P, Mannant PR, Borderie C, Ripault MP, Silvain C, Beauchant M. Early feeding or enteral nutrition in patients with cirrhosis after bleeding from esophageal varices? A randomized controlled study. Dig Dis Sci 1997;42:536-41.

33. Bories B, Campillo B. One-month regular oral nutrition in alcoholic cirrhotic patients. Changes of nutritional status, hepatic function and serum lipid pattern. Br J Nutr 1994;72:937-46.

34. Naylor CD, Rourke K, Detsky AS, Baker JP. Parenteral nutrition with branched chain amino acids in hepatic encephalophathy. A meta-analysis. Gastroenterology 1989;97:1033-42.

35. Bonkovsky HL, Singh RH, Jafri IH, Fiellin DA, Smith GS, Simon D, Cotsonis GA, Slaker DP. A randomized controlled trial of the treatment of alcoholic hepatitis with parenteral nutrition and oxandrolon II: shortterm effects on nitrogen metabolism, metabolic balance and nutrition. $\mathrm{Am}$ J Gastroenterol 1991;86:1209-18.

36. Swart GR, Van den Berg JWO, Vuure JK, Tietveld T, Wattimena DL, Frenkel M. Minimum protein requirements in liver cirrhosis determined by nitrogen balance measurements at three levels of protein intake. Clin Nutr 1989;8:329-36.

37. Morgan M, Madden A, Jennings G, Elia M, Fuller NJ. Two-component models are of limited value for the assessment of body composition in patients with cirrhosis. Am J Clin Nutr 2006;84:1151-62.

38. Nielsen BK, Kondrup J, Martinsen L, Dossing H, Larsson B, Stilling B, Jensen MG. Long-term oral refeeding of patients with cirrhosis of the liver. Br J Nutr 1995;74:557-67.

39. Khanna S, Gopalan S. Role of branched-chain amino acids in liver disease: the evidence for and against. Curr Opin Nutr Metab Care 2007;10:297-303.

40. Mardini HA, Douglass A, Record C. Amino acid challenge in patients with cirrhosis and control subjects: ammonia, plasma amino acid and EEG changes. Metab Brain Dis 2006;21:1-10.

41. Bianchi G, Marzocchi R, Agostini F, Marchesini G. Update on nutritional supplementation with branched-chain amino acids. Curr Opin Clin Nutr Metab Care 2005;8:83-7.

42. Plauth M, Egberts EH, Hamster W, Török M, Müller PH, Brand O, Fürst P, Dölle W. Long-term treatment of latent portosystemic encephalopathy with branched-chain amino acids. A double-blind placebo-controlled crossover study. J Hepatol 1993;17:308-14.

43. Marchesinin G, Bianchi G, Merli M, Amodio P, Panella C, Loguercio C, Rossi Fanelli F, Abbiati R; Italian BCAA Study Group. Nutritional supplementation with branched chain amino acids in advanced cirrhosis: a double blind, randomized trial. Gastroenterology 2003;124:1792-801.

44. Fukushima H, Miwa Y, Ida E, Kuriyama S, Toda K, Shimomura Y, Sugiyama A, Sugihara J, Tomita E, Moriwaki H. Nocturnal branchedchain amino acid administration improves protein metabolism in patients with liver cirrhosis: comparison with daytime administration. $J$ Parenter Enteral Nutr 2003;27:315-22.

45. Plauth M, Merli M, Kondrup J., Weimann A, Ferenci P, Müller MJ; ESPEN Consensus Group. ESPEN guidelines for nutrition in liver disease and transplantation. Clin Nutr 1997;16:43-55.

46. Mizock BA. Nutritional support in hepatic encephalopathy. Nutrition 1999;15:220-8

47. Als-Nielsen B, Koretz RL, Gluud LL, Gluud C. Branched-chain amino acids for hepatic encephalopathy. Cochrane Database Syst Rev 2003;2:CD001939.

48. Muller MJ. Malnutrition in cirrhosis. J Hepatol 1995;23 Suppl 1:31-5.

49. Leevy CM, Moroianu SA. Nutritional aspects of alcoholic liver disease. Clin Liver Dis 2005;9:67-81.

50. Leo MA, Lieber CS. Hepatic vitamin A depletion in alcoholic liver injury. N Engl J Med 1982;307:597-601

51. Hay JE, Guichelaar MM. Evaluation and management of osteoporosis in liver disease. Clin Liver Dis 2005;9:747-66.

52. Sainz J, Van Tornout JM, Loro L, Sayre J, Roe TF, Gilsanz V. Vitamin D receptor gene polymorphisms and bone density in prepubertal American girls of Mexican descent. N Engl J Med 1997;337:77-82.

53. Sharma R, Rakela J. Management of pre-liver transplantation patient: part 2. Liver Transpl 2005;3:249-60.

54. Lochs H, Plauth M. Liver cirrhosis: rationale and modalities for nutritional support-the European Society of Parenteral and Enteral Nutrition consensus and beyond. Curr Opin Clin Nutr Metab Care 1999;2:345-9.

55. Aggett PJ. Severe zinc defiency. In: Mills CF, editor. Zinc in human biology. Berlin: Springer; 1989. p. 259-74.

56. Raynard B, Balian A, Fallik D, Capron F, Bedossa P, Chaput JC, Naveau $\mathrm{S}$. Risk factors of fibrosis in alcohol-induced liver disease. Hepatology 2002;35:635-8.

57. Bamgbade OA, Tait AR, Kheterpal S, Nafiu OO, Dorje P, Pelletier SJ. Magnesium supplementation during liver transplantation. Internet J Surg 2008;15:1.

58. Hasse JM. Nutritional implications of liver transplantation. Henry Ford Hosp Med J 1990;38:235-40.

59. Hasse J. Role of the dietitian in the nutrition management of adults after liver transplantation. J Am Diet Assoc 1991;91:473-6.

60. Hasse JM. Nutrition considerations in liver transplantation. Top Clin Nutr 1992;7:24-33.

61. Munoz SJ. Nutritional therapies in liver disease. Semin Liver Dis 1991;11:278-91.

62. Hasse JM, Blue LS, Crippin JS, Goldstein RM, Jennings LW, Gonwa TA, Husberg BS, Levy MF, Klintmalm GB. The effect of nutritional status on 
length of stay and clinical outcomes following liver transplantation. J Am Diet Assoc 1994;94:A38.

63. Plauth M, Cabre E, Riggio O, Assis-Camilo M, Pirlich M, Kondrup J; DGEM (German Society for Nutritional Medicine), Ferenci P, Holm E, Vom Dahl S, Müller MJ, Nolte W; ESPEN (European Society for Parenteral and Enteral Nutrition). ESPEN guidelines on enteral nutrition: liver disease. Clin Nutr 2006;25:285-94.

64. Sandu BS, Sanyal AJ. Management of ascites in cirrhosis. Clin Liver Dis 2005;9:715-32.

65. Ginés P, Berl T, Bernardi M, Bichet DG, Hamon G, Jiménez W, Liard JF, Martin PY, Schrier RW. Hyponatremia in cirrhosis: from pathogenesis to treatment. Hepatology 1998;28:851-64.

66. Runyon B; Practice Guidelines Committee, American Association for the Study of Liver Diseases (AASLD). Management of adult patients with ascites due to cirrhosis. Hepatology 2004;39:841-56.

67. Plauth M, Schutz T, Buckendahl DP, Kreymann G, Pirlich M, Grüngreiff S, Romaniuk P, Ertl S, Weiss ML, Lochs H. Weight gain after transjugular intrahepatic portosystemic shunt is associated with improvement in body composition in malnourished patients with cirrhosis and hypermetabolism. $J$ Hepatol 2004;40:228-33.

68. Sheth AA, Garcia-Tsao G. Probiotics and liver disease. $J$ Clin Gastroenterol 2008;42:S80-4.

69. Rayes N, Seehofer D, Theruvath T, Schiller RA, Langrehr JM, Jonas S, Bengmark S, Neuhaus P. Supply of pre and probiotics reduces bacterial infection rates after liver transplantation-a randomized, doubleblind trial. Am J Transplant 2005;5:125-30.

70. Stadlbauer V, Mookerjee RP, Hodges S, Wright GAK, Davies NA, Jalan R. Effect of probiotic treatment on deranged neutrophil function and cytokine responses in patients with compensated alcoholic cirrhosis. $J$ Hepatol 2008;48:945-51.

71. Sharma P, Sharma BC, Puri V, Sarin SK. An open-label randomized controlled trial of lactulose and probiotics in the treatment of minimal hepatic encephalopathy. Eur J Gastroenterol Hepatol 2008;20:506-11.

72. Bajaj JS, Saeian K, Christensen KM, Hafeezullah M, Varma RR, Franco J, Pleuss JA, Krakower G, Hoffmann RG, Binion DG. Probiotic yogurt for the treatment of minimal hepatic encephalopathy. Am J Gastroenterol 2008;103:1707-15.

73. Tandon P, Moncrief K, Madsen K, Arrieta MC, Owen RJ, Bain VG, Wong WW, Ma MM. Effects of probiotic therapy on portal pressure in patients with cirrhosis: a pilot study. Liver Int 2009;29:1110-5.

74. Lata J, Novotny I, Pribramska V, Juránková J, Frič P, Kroupa R, Stibůrek $\mathrm{O}$. The effect of probiotics on gut flora, level of endotoxin and ChildPugh score in cirrhotic patients: results of a double blind randomized study. Eur J Gastroenterol Hepatol 2007;19:1111-3.

75. Plank LD, McCall JL, Gane EJ, Rafique M, Gillanders LK, McIlroy K, Munn SR. Pre and postoperative immunonutrition in patients undergoing liver transplantation: a pilot study of safety and efficacy. Clin Nutr 2005;24:288-96.

76. Qiu Y, Zhu X, Wang W, Xu Q, Ding Y. Nutrition support with glutamine dipeptide in patients undergoing liver transplantation. Transplant Proc 2009;41:4232-7.

77. Plank LD, Gane EJ, Peng S,Muthu C,Mathur S, Gillanders L, McIlroy K, Donaghy AJ, McCall JL. Nocturnal nutritional supplementation improves total body protein status of patients with liver cirrhosis: a randomized 12-month trial. Hepatology 2008;48:557-66.
78. Zillikens MC, van den Berg JW, Wattimena JL, Rietveld T, Swart GR. Nocturnal oral glucose supplementation. The effects on protein metabolism in cirrhotic patients and in healthy controls. $J$ Hepatol 1993; 17:377-83.

79. Stickel F, Hoehn B, Schuppan D, Seitz HK. Review article: nutritional therapy in alcoholic liver disease. Aliment Pharmacol Ther 2003;18:357-73.

80. Halsted CH. Nutrition and alcoholic liver disease. Semin Liver Dis 2004;24:289-304.

81. Hirsch S, Bunout D, De la Maza P, Iturriaga H, Petermann M, Icazar G, Gattas V, Ugarte G. Controlled trial on nutrition supplementation in outpatients with symptomatic alcoholic cirrhosis. J Parenter Enteral Nutr 1993;17:119-24.

82. Mendenhall CL, Moritz TE, Roselle GA, Morgan TR, Nemchausky BA, Tamburro CH, Schiff ER, McClain CJ, Marsano LS, Allen JI. A study of oral nutritional support with oxandrolone in malnourished patients with alcoholic hepatitis: results of a Department of Veterans Affairs cooperative study. Hepatology 1993;17:564-76.

83. Le Cornu KA, McKiernan FJ, Kapadia SA, Neuberger JM. A prospective randomized study of preoperative nutritional supplementation in patients awaiting elective orthotopic liver transplantation. Transplantation 2000;69:1364-9.

84. Kawaguchi T, Taniguchi E, Itou M, Mutou M, Ibi R, Shiraishi S, Okada T, Uchida Y, Otsuka M, Tonan T, Fujimoto K, Oriishi T, Tanaka S, Takakura M, Sata M. Supplement improves nutrition and stresses caused by examination-associated fasting in patients with liver cirrhosis. Hepatol Res 2008;38:1178-85.

85. CabreÂ E, Periago JL, Abad A, González HF, González J, Esteve-Comas M, Fernández-Bañares F, Planas R, Gil A, Sánchez-Medina F. Plasma fatty acid profile in advanced cirrhosis: unsaturation deficit of lipid fractions. Am J Gastroenterol 1990;85:1597-604.

86. Cabre E, Gassull MA. Nutrition in liver disease. Curr Opin Nutr Metab Care 2005;8:545-51.

87. Hasse JM, Blue LS, Liepa GU, Goldstein RM, Jennings LW, Mor E, Husberg BS, Levy MF, Gonwa TA, Klintmalm GB. Early enteral nutrition support in patients undergoing liver transplantation. J Parenter Enteral Nutr 1995;19:437-43.

88. Fan ST, Lo CM, Lai EC, Chu KM, Liu CL, Wong J. Perioperative nutritional support in patients undergoing hepatectomy for hepatocellular carcinoma. N Engl J Med 1994;331:1547-52.

89. Wicks C, Somasundaram S, Bjarnason I, Menzies IS, Routley D, Potter D, Tan KC, Williams R. Comparison of enteral feeding and total parenteral nutrition after liver transplantation. Lancet 1994;344:837-40.

90. DiCecco SR, Ziller NF. Nutrition in alcoholic liver disease. Nutr Clin Pract 2006;21:245-54.

91. Weimann A, Braga M, Harsanyi L, Laviano A, Ljungqvist O, Soeters P; DGEM (German Society for Nutritional Medicine), Jauch KW, Kemen M, Hiesmayr JM, Horbach T, Kuse ER, Vestweber KH; ESPEN (European Society for Parenteral and Enteral Nutrition). ESPEN Guidelines on Enteral Nutrition: surgery including organ transplantation. Clin Nutr 2006;25:224-44.

92. Plauth M, Cabré E, Campillo B, Kondrup J, Marchesini G, Schütz T, Shenkin A, Wendon J; ESPEN. ESPEN guidelines on parenteral nutrition: hepatology. Clin Nutr 2009;28:436-44. 